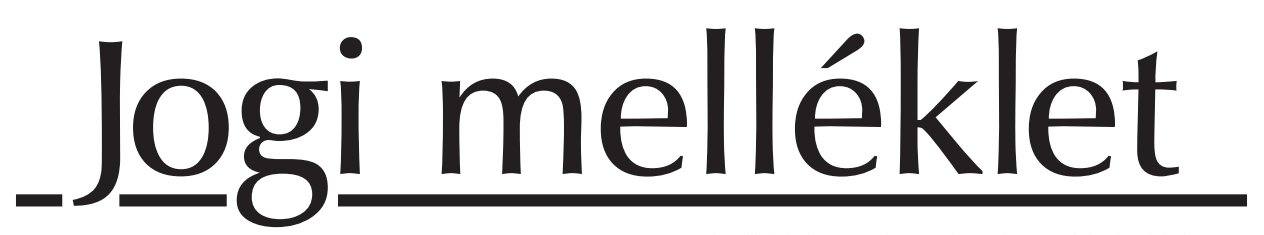

Külgazdaság, LXV. évf., 2021. május-június (106-121. o.)

\title{
A nemzetközi beruházási konfliktusok vitarendezésének sajátos útja: az Achmea-ügy és hatása*
}

\section{SZALAI ILDIKÓ}

E tanulmány középpontjában egy beruházásvédelemmel kapcsolatos választottbirósági eljárás áll, amelyet az Európai Unió Biróságának elözetes döntéshozatali eljárása során hozott itélete és annak hatására bekövetkezett radikális változás kísért. Ez az Achmeaitélet, amely az uniós beruházásvédelmi jog jelentös mérföldköve. A 2018. március 6-án hozott döntés értelmében a tagállamok közötti beruházások ösztönzésére és védelmére irányuló megállapodások nemzetközi választottbirósági klauzulája összeegyeztethetetlen az uniós joggal. Az Európai Unió Bíróságának döntését sok kritika érte rövid és nem teljesen egyértelmü konklúziója miatt, miszerint inkább fokozta az uniós jog és a nemzetközi jog konfliktusát, minthogy azt elsimitotta volna. Az Achmea-ügyben hozott döntés csupán elöszele volt az uniós rezsim expanziójának, aminek bizonyitási alapjaként az itélet meghozatalát követö jogalkotói és jogalkalmazói mechanizmus szolgál. A döntés differens értelmezésével az uniós jog expanziós vihara napjainkban sem csitul.

Journal of Economic Literature (JEL) kódok: K33, K40, K41.

Kulcsszavak: kétoldalú beruházásvédelmi megállapodás, jogi pluralizmus, uniós jog szupremáciája és autonómiája, választottbírósági eljárásra vonatkozó rendelkezés.

Dr. Szalai Ildikó vezető-kormánytanácsos, Külgazdasági és Külügyminisztérium, Kereskedelempolitikai Főosztály; PhD-hallgató, Pázmány Péter Katolikus Egyetem, Jog- és Államtudományi Kar, Nemzetközi Magánjogi Tanszék. E-mail: ldk.szalai@gmail.com.

Jelen tanulmányban foglalt megállapítások kizárólag a szerző álláspontját tükrözik.

A szerző hálás köszönetét fejezi ki dr. Raffai Katalin egyetemi docens asszonynak a tanulmány létrejöttéhez nyújtott támogatásáért és szakmai észrevételeiért.

* A kézirat első változata 2021. május 30-án érkezett szerkesztőségünkbe.

https://doi.org/10.47630/KULG.2021.65.5-6.106 
A nemzetközi beruházási konfliktusok vitarendezésének sajátos útja...

Abstract

\section{The unique process of dispute settlement on international investment conflicts: the Achmea case and its impact \\ ILDIKÓ SZALAI}

This study focuses on an arbitration process, accompanied by a preliminary ruling procedure by the Court of Justice of the European Union and the subsequent radical change. This is the so-called Achmea judgment, which is a major milestone in the EU policy of international investment law. According to the decision of 6 March 2018, the arbitration clauses in EU-internal bilateral investment treaties are incompatible with EU law. Due to its short and not entirely clear conclusion, it has been widely criticized for exacerbating rather than mitigated the conflict between EU law and international law. The decision in the Achmea case was only a premonitory sign of the expansion of EU regime, which is evidenced by the legislative and enforcement mechanism following the judgment. Regarding the divergent interpretation of the decision, the expansion storm of EU law does not abate even nowadays.

Journal of Economic Literature (JEL) codes: K33, K40, K41.

Keywords: bilateral investment treaty, legal pluralism, supremacy and autonomy of European Union law, arbitration clause.

\section{Bevezető}

A modern beruházásvédelmi jog a második világháború befejezése után alakult ki a dekolonizációs folyamatokra adott nemzetközi jogi válaszként (Prieto-Rios, 2015:57), többségében kétoldalú nemzetközi szerződések formájában (bilateral investment treaty - a továbbiakban BIT). A BIT-ek olyan megállapodások, amelyek meghatározzák egy állam jogalanyai másik államban történő beruházásainak általános feltételeit, kiépítik azok jogi feltétel- és garanciarendszerét. Lényegében a posztkolonializmus mesterséges konstrukciói, amelyek alapjait a neoliberalizmus eszméjének elterjedése, a befektetőbarát szabadpiaci rendszer létrehozása alakította ki.

Jelenleg a világ legtöbb országát érintik ezek a megállapodások, mert több mint kétezer BIT van hatályban. ${ }^{1}$ Napjainkban azonban a nemzetközi beruházási jogi rezsim átalakulóban van. A változás legfontosabb eleme, hogy kivennék belőle a szerződések vitarendezésére vonatkozó általános szabályát, vagyis a választottbírósági klauzulát (investor-state dispute settlement - ISDS-kikötés). Ennek (elméleti)

12852 érvényes kétoldalú beruházási szerződésből 2298 hatályban van (2021. 04. 23.). https:// investmentpolicy.unctad.org/international-investment-agreements 
legfőbb oka: az államok meghatározott célokért korlátozták legitimitásuk erejét, de sok esetben a választottbírósági értelmezés eltér attól, mint ami ezen országokat a szerződés megkötésekor vezérelte (Subedi, 2016:10).

A kétpólusú világ megszünésével és az azt követő stagnáló évtizedek után napjaink törekvéseit már-már a paradigmaváltás fogalmi körével illethetnénk, azonban a változás továbbra is fokozatos reformokban mutatkozik meg. A fokozatosság az Európai Uniót (a továbbiakban EU) mint szupranacionális jogrendet is jellemzi. Emellett szintén jellemzi az uniós jog szupremáciájának hirdetése, ami által uniós relációban megkérdőjelezetté válik az uniós jogtól függetlenül létrejött nemzetközi választott bíróság vitarendezési joghatósága. Magyarország és a többi tagállam esetében is az unió területéhez kapcsolódóan és a tagállamok egymás közti viszonyaiban az uniós jognak elsőbbsége van, az megkerülhetetlen. Ám mi történik akkor, ha az arbitrázs hatáskörébe utalt vitarendezéskor az uniós törekvés és a rá reflektáló nemzetközi jogi környezet inkoherens képet mutat? Mégis milyen feltételekkel képes e két jogi rezsim hatékonyan együttműködve létezni?

Jelen tanulmány célja a teljesség igénye nélkül az esetjoggal szemléltetve rávilágítani az uniós és nemzetközi jog közötti, a jogi pluralizmus okozta dimenzió zavarára. Az elemzés középpontjában egy beruházásvédelemmel kapcsolatos olyan választottbírósági eljárás áll, amelyet az Európai Unió Bíróságának (a továbbiakban: EUB) előzetes döntéshozatali eljárása során hozott ítélete és annak hatására radikális változás kísért. Ez az Achmea-ügyben ${ }^{2}$ született döntés, amely a beruházásvédelem területén - az uniós jog szupremáciájának és autonómiájának kinyilvánításával felgyorsította az EU „expanziós” törekvéseit.

Az EUB ítéletének meghozatalát nagy várakozás előzte meg, mivel az mind intézményi, mind gazdasági és szakpolitikai változást ígért, az uniós jog és nemzetközi jog közötti intézményi rend alaposabb kiértékelésével. Fö kérdése arra irányult, hogy az unión belüli BIT-ekbe foglalt választottbírósági eljárásra vonatkozó rendelkezések veszélyeztetik-e az EU autonómiáját. A sorok között viszont megbújik a jogi pluralizmus problematikája is, amely egy állandó és koherens nemzetközi beruházási jog hiányából és az uniós jog sajátos, sui generis jellegéből ered.

Az tény, hogy a jogi pluralizmus létezik (Griffiths, 1986:4). Képviseletében élen jár az Európai Unió, ahol az elmúlt évtizedekben a huszonhét tagállam vonatkozásában egy nemzetek feletti átfogó közösség képe bontakozott ki. Ellenben a normatív képesség ereje jelentős mértékben csökkenhet, ha egy szupranacionális jogrend -

2 C-284/16. sz. ügy, The Slovak Republic kontra Achmea BV, EUB (nagytanács) 2018. március 6-i ítélet (ECLI:EU:C:2018:158) 
egyenlő alapon az államokkal - ugyanolyan autonómnak vallja magát. Sőt mi több, a jelen esetre kivetítve: az EU a tagállamok jogát megelőzve, az uniós jog elsőbbségét hirdetve egy olyan tényállásban igyekszik plauzibilis vitarendező joghatóságát megőrizni, amelynek jogalapja a nemzetközi jogban gyökeredzik (Avbelj, 2006:382). A kérdés az, hogy jogosan teszi ezt? Mit igazol az Achmea-döntés és az azt követő jogalkalmazási és jogalkotási mechanizmus?

Az Achmea-ügy kritikusai szerint a döntés rövid terjedelme ellenére sem egyértelmű. Ahelyett, hogy az eddigi kérdéseket megválaszolta volna, még többet vetett fel. A jogértelmezés legelfogadottabb felfogását alapul véve és látva az Achmea-döntés hozadékát, lehetséges viszont, hogy éppen ez az EUB-döntés segíti a két rezsim közötti konfliktus következetesebb feloldását, ami abban az esetben valósulhat meg, ha a döntés értelmezése elegendő mozgásteret biztosít a beruházásvédelmi jog érdekelt felei számára. Az Achmea-döntést pártolók az EUB-ítéletet egyfajta összekötő kapocsként, valóságos hídként üdvözölték a nemzetközi jog és az uniós jog közötti diszharmóniában (Amariles et al., 2020:908).

\section{Pluralista jelleg kibontakozóban}

A beruházásvédelmi jog a nemzetközi jog sajátos területe, amely részben nemzetközi közjogi, részben pedig nemzetközi gazdasági jogi viszonyokat szabályoz. Ráadás specifikuma az, hogy az alapul szolgáló, államok által megkötött egyezmények ISDS-kikötései ${ }^{3}$ az egyik szerződő fél területén lévő beruházással kapcsolatos viták vonatkozásában a másik szerződő fél beruházójának ad jogosultságot. Élénk vita tárgya a joghatóság kérdésköre, miként az ügy érdemére vonatkozó alkalmazandó jog meghatározása is, mert releváns rendelkezések a nemzetközi jog alapelvein, a nemzetközi szerződések anyagi jogi és eljárásjogi jogszabályhelyein túl a nemzetközi választott bíróságokra irányadó szabályzatok is. A vitarendezés során ugyanakkor az államok közpolitikai intézkedései válnak vizsgálat tárgyává.

Másrészt a beruházásvédelmi jogot a nemzetközi színtéren megszokott univerzális egyezményi rendszerrel szemben a diverzitás jellemzi. Jogi kerete, ahogy eddig láttuk, többségében kétoldalú megállapodásokban rejlik, de előtérbe kerülnek a multilaterális szerződések, a regionális megállapodások és a soft law eszközei is. A különféle jogforrások rendszere ezáltal - az eltérő szabályozás révén - eltérő védelmet

\footnotetext{
${ }^{3}$ Investor-state dispute settlement (ISDS), vagyis a beruházó és az állam közötti vitarendezési mechanizmus elnevezése.
} 
nyújt a külföldi közvetlen befektetéseknek (foreign direct investment - FDI), ami még nagyobb kihívást jelent abban, hogy egy konstans nemzetközi beruházásvédelmi rendszer alakuljon ki, vagyis a jogi pluralizmus a nemzetközi beruházási jog esetében inkább alapvető attribútum, mintsem kivétel (Amariles et al., 2020:917). Ez a nemzetközi jog sajátos formájának tekintett uniós jog berkein belül fokozottan igaz. Az Európai Unió jogának éppen ez a sajátos, sui generis jellege erősíti még inkább a jogi pluralista nézetet. Az elmúlt évtizedben az EU a nemzetközi választott bíróságok, ad hoc vitarendezési panelek joghatóságát, sőt a tagállamok közötti BIT-ek létezését is megkérdőjelezte, miközben a választottbírósági eljárások eredményeként jogerős ítéletek születtek.

\subsection{Az uniós jog a beruházásvédelemben}

A Lisszaboni Szerződés hatálybalépése óta ${ }^{4}$ az uniós beruházásvédelem területe jelentősebb fejlődésen ment keresztül, mert az európaizálódás folyamatának jelenlegi szakaszában a tagállamok közötti beruházásvédelem a belső piac, míg a külföldi közvetlen befektetések rendszere a közös kereskedelempolitika részévé vált. Ebböl ugyan arra lehetne következtetni, hogy a tagállamok egymással kötött megállapodásai nagyobb teret kapnak a kizárólagosan uniós hatáskörbe tartozó harmadik állammal kötött BIT-ekkel szemben, azonban a valóság mást takar. Az 1219/2012/EU rendelet ${ }^{5}$ átmeneti rendelkezései felhatalmazást adtak a tagállamok számára, hogy megállapodást kössenek, amíg azt az EU nem vonja tényleges hatásköre alá, a jogbiztonság megteremtése érdekében hangsúlyozottan magukba foglalva a megreformált uniós megközelítés kulcsfontosságú elemeit és normáit. Ezzel szemben az EU a tagállamok közötti BIT-ek rendszerét ma már kifejezetten felszámolni igyekszik, amihez a kezdeti lökést az Achmea-ítélet adta.

\subsection{Az Intra-EU BIT-ek felszámolására tett kísérletek}

Az Európai Bizottság (a továbbiakban EB) többszörösen kísérletet tett a belső piaci anomáliaként ${ }^{6}$ titulált helyzet megszüntetésére. Az Eastern Sugar v. Czech Re-

${ }^{4}$ Lisszaboni szerződés (2007. december 13.) az Európai Unióról szóló szerződés és az Európai Közösséget létrehozó szerződés módosításáról (HL 306/01, 2007. 12. 17.).

${ }^{5}$ Az Európai Parlament és a Tanács 1219/2012/EU rendelete (2012. december 12.) a tagállamok és harmadik országok közötti kétoldalú beruházási megállapodások tekintetében átmeneti rendelkezések megállapításáról (HL 351/40, 2012. 12. 20.)

${ }^{6}$ Achmea B. V. v The Slovak Republic, PCA Case No. 2008-13 (korábban Eureko B. V. v The Slovak Republic), Award on Jurisdiction, Arbitrability, and Suspension (26 October 2010) (Achmea Award on Jurisdiction) 177. p. 
public-ügyben ${ }^{7}$ megfogalmazott állásfoglalásában kifejtette, hogy az uniós jog értelmezésekor a választott bíróságok az EU égisze alatt nem gyakorolhatnak joghatóságot, amire a tagállamok többsége (alperesi oldalon) a választottbírósági panelek előtt tett hatásköri kifogásukban szintén hivatkoztak. Majd az EB későbbiekben amicus curiae-ként fellépve további érvekkel állt elö, ami még inkább képlékennyé tette a beruházási jogviták rendezésére alakult panelek döntéseinek de jure létét.

Alapvetően specifikusabbá teszi a helyzetet, hogy az adott témakörben a jogértelmezés valamelyest mindig kontextusfüggő, hiszen míg az EB az uniós jog elsőbbségének elvéből indult ki, addig a nemzetközi beruházási választott bíróság léte nemzetközi jogi alapokból származik.

A fentebb megfogalmazottak értelmében az unión belüli BIT-ek két perspektívája eltérő megállapítást eredményezett (Szabados, 2017:18). A nemzetközi jog oldaláról a tagállami BIT és az abban foglalt ISDS-kikötés addig hatályban marad, amíg a beruházásvédelmi megállapodás a szerződések jogáról szóló bécsi egyezmény ${ }^{8}$ ( továbbiakban BE) 59. cikke értelmében meg nem szűnik, ami a BE 65-68. cikkben lefektetett eljárási szabályok szerint történik. Ellenben e BIT-ek esetében e formális kritériumok nem valósultak meg. ${ }^{9}$

$\mathrm{Az}$ uniós jog értelmében a BE 30. cikkének 3. pontja szerint a lex posterior derogat legi priori elv vált irányadóvá. Legalább részleges átfedés van az unión belüli BIT-ek és az Európai Unió müködéséről szóló szerződésbe ${ }^{10}$ (a továbbiakban EUMSZ) foglalt rendelkezések között, ami megkérdőjelezi a tagállami beruházásvédelmi megállapodások létét. Tehát a $\mathrm{BE} 30$. cikkének e pontja feltételezi a normák ütközését (Nagy, 2018:1000). Ez a helyzet aláássa az uniós jog szupremáciáját és autonómiáját azáltal is, hogy a megkülönböztetés tilalma elvének ${ }^{11}$ megsértésével - gazdasági érdekszemlélettel - az egyenlötlen versenyfeltételek torzító hatással lehetnek a belső piacra (Bartha, 2015:194). Az EUB állandó ítélkezési gyakorlatára hivatkozva, ${ }^{12}$ ha a nemzetközi megállapodások megsértik a hatásköri rendet, úgy az

7 Eastern Sugar B. V. (Netherlands) v. The Czech Republic, SCC Case No. 088/2004

${ }^{8}$ Vienna Convention on the Law of Treaties; az 1987. évi 12. törvényerejü rendelet - a szerződések jogáról szóló, Bécsben 1969. évi május hó 23. napján kelt szerződés kihirdetéséről.

9 L. Achmea B.V. v. The Slovak Republic, UNCITRAL, PCA Case No. 2008-13 231-238. p.

${ }^{10}$ Európai Unió működéséről szóló szerződés (HL 326/01, 2012. 10. 26.)

${ }^{11}$ EUMSZ 18. cikke kifejeződése: Eastern Sugar v. The Czech Republic c. (Final Award) 106. cikke; Achmea v. The Slovak Republic c. (Award on Jurisdiction) 183-184. cikke

${ }^{12}$ L. 1/91 vélemény, (EU:C:1991:490) 35. p.; 1/00 vélemény, (EU:C:2002:231) 11. és 12. p.; C-459/03 c. Bizottság kontra Írország ítélet, (EU:C:2006:345) 123. és 136. p.; Kadi és Al Barakaat International Foundation kontra Tanács és Bizottság ítélet, (EU:C:2008:461) 282. pontja; Costa-ítélet, (EU:C:1964:66) 1159. és 1160. o.; Internationale Handelsgesellschaft ítélet, (EU:C:1970:114) 3. p.; 1/09 vélemény, (EU:C:2011:123) 68. p. 
uniós jogrend autonómiáját is. Az uniós jog tiszteletben tartását és alkalmazását biztosítani kell. Mindez az Európai Unióról szóló szerződés ${ }^{13}$ (a továbbiakban EUSZ) 4. cikk (3) bekezdésének első albekezdésébe foglalt lojális együttmüködés elvéből eredeztethető, valamint az EUSZ 2. cikkéből is, ami megerősíti a tagállamok közötti kölcsönös bizalom fennállását (Mohay, 2019:55).

Továbbá szükséges kiemelni, hogy a jelenleg intra-EU BIT-ekként említett nemzetközi megállapodások többsége az EU-hoz történő csatlakozás előtt jött létre, mintegy extra-BIT-ként. Az EU-hoz történő csatlakozással azonban az EUMSZ 351. cikke $^{14}$ a tagállamok közötti BIT-ek esetében nem hivatkozható, mert az uniós jog elsőbbsége általánosan elfogadott tény. ${ }^{15}$ Uniós joggal összeegyeztethetetlen tagállamok közötti szerződések nem lehetnek hatályban (Szabados, 2017:24-25). ${ }^{16}$ A gyakorlat azonban nem az uniós elméleti tézis beigazolódásához vezetett. Mivel a választottbírósági panelek a nemzetközi jogból származtatják létjogosultságukat, ezért az intra-EU BIT-ekben megtalálható specifikus jogszabályhely, a választott bírósághoz fordulás joga a másik tagállam beruházói számára ekkor még nyílt terepet kínált a jogviták ilyen módon történő rendezéséhez.

2015-ben az EB egyes BIT-ek explicit megszüntetésére öt tagállammal szemben is kötelezettségszegési eljárást indított, ${ }^{17}$ ám az sem vezetett átfogó eredményhez. Ahogy a Micula testvérek kontra Románia-ügyben ${ }^{18}$ tett állásfoglalása sem javított

${ }^{13}$ Európai Unióról szóló szerződés (HL 326/01, 2012. 10. 26.)

${ }^{14}$ EUMSZ 351. cikke (az EKSZ korábbi 307. cikke):

„Az egyrészröl e gy vagy több tagállam, másrészröl egy vagy több harmadik állam által egymás között 1958. január 1-je elött, illetve a csatlakozó államok esetében a csatlakozásukat megelözöen kötött megállapodásokból eredö jogokat és kötelezettségeket a Szerzödések rendelkezései nem érintik.

Annyiban, amennyiben ezek a megállapodások nem egyeztethetöek össze a Szerzödésekkel, az érintett tagállam vagy tagállamok megteszik a megfelelö lépéseket a megállapított összeegyeztethetetlenség kiküszöbölésére. A tagállamok e cél érdekében szükség esetén segitséget nyújtanak egymásnak, és amennyiben indokolt, egységes magatartást tanúsitanak.

Az elsö bekezdésben emlitett megállapodások alkalmazása során a tagállamok figyelembe veszik azt, hogy a Szerzödések szerint az egyes tagállamok által nyújtott elönyök az Unió létrehozásának szerves részét képezik, és ezáltal elválaszthatatlanul összekapcsolódnak a közös intézmények létrehozásával, ez utóbbiak hatáskörrel történö felruházásával, valamint ugyanilyen elönyöknek az összes többi tagállam részéről történö biztositásával."

15 C-10/61 sz. ügy Commission v. Italy (EU:C:1962:2); C-286/86. sz. ügy Deserbais (EU:C:1988:434)

${ }^{16}$ L. továbbá C-482/09. sz. ügy Budějovický Budvar kontra Anheuser-Busch Inc., EUB 2011. szeptember 22-i ítélet (ECLI:EU:C:2011:605): két tagállam között létrejött nemzetközi megállapodásban rögzítettek nem alkalmazhatók az adott két tagállam viszonylatában, ha megállapítható, hogy azok az uniós szerződésekbe ütköznek.

${ }^{17}$ Commission Asks Member States to Terminate Their Intra-EU Bilateral Investment Treaties (Press Release, IP/15/5198, 2015)

${ }^{18}$ Ioan Micula, Viorel Micula, S. C. European Food S.A., S.C. Starmill S.R.L. and S.C. Multipack S.R.L. v. Romania, ICSID Case No. ARB/05/20 
a helyzeten..$^{19} \mathrm{Az}$ EU-ban egészen a 2010-es évek második feléig várni kellett arra, hogy az Achmea versus Szlovák Köztársaság választottbírósági eljárással kapcsolatos EUB általi előzetes döntéshozatali eljárásában, megfelelő jogi keretek között nyilatkozhasson a tagállamok között fennálló BIT-ek egyes rendelkezéseinek uniós joggal való összeegyeztethetőségéről, mert az EUB-nak kizárólagos hatásköre van az uniós jog egységes értelmezésére. Van olyan álláspont, mely szerint ez a szerepkör a saját jogi értékrenddel bíró unióban egy alkotmánybírósághoz hasonlítható (Somssich, 2019:128).

\section{Az Achmea-ügy tényállása}

A Union Healthcare az Achmea leányvállalataként megjelent a szlovák piacon, miután azt az uniós befektetők elött megnyitották. Azonban 2006-ban az újonnan választott kormány változtatott törekvésein, részben visszaállamosítva a piacot, érintve a fentebb megnevezett holland beruházó gazdasági tevékenységét is. Válaszul az Achmea választottbírósági eljárás $\mathrm{t}^{20}$ indított Szlovákiával szemben, alapul véve a csehszlovák-holland BIT-ben ${ }^{21}$ szereplő ISDS-rendelkezést. ${ }^{22}$ A választottbírósági eljárás során Szlovákia hatásköri kifogást nyújtott be, vitatva az eljáró panel jogosultságát a jogvita eldöntésére. A szlovák állam uniós tagságára hivatkozott, ezt alapul véve, álláspontja szerint csatlakozásával e szerződés hatálytalanná vált. A felperes szerint azonban Szlovákia ezáltal hárította volna kötelezettségét, ahogy végül a bíróság is elutasította a hatáskörének hiányára tett szlovák indítványt. Ha a BITeket sértő cselekmény uniós jog alapján kifejezetten kötelező lenne, tartalmazná azt az EUMSZ. A BIT-ben garantált jogok nem feltétlenül jelennek meg az uniós jog-

19 L. továbbá EB-határozat 2015/1470 (L 232/43, 2015. 4. 9.): a Micula-ügyben tett észrevételei alapján a nemzetközi választott bíróság általi ítéletben (I. Micula, V. Micula, S.C. European Food S.A, S.C. Starmill S.R.L. and S.C. Multipack S.R.L. v. Romania, ICSID Case No. ARB/05/20, Final Award) megállapított kártérítés az európai uniós állami támogatási politikára vonatkozó szabályokkal ellentétes. A Bizottság szerint függetlenül attól, hogy a Micula testvérek jogérvényesítésének alapja Románia uniós csatlakozását megelőzően keletkezett. EUB ítéletében (T 624/5 c. European Food és társai kontra Bizottság, EUB törvényszék ítélete (kibővített második tanács, [ECLI:EU:T:2019:423]) a Bizottság hatáskörének hiányáról és az uniós jognak a Románia csatlakozása előtti helyzetekre való alkalmazhatatlanságáról döntött, és megsemmisítette az EB határozatát.

20 Achmea B.V. v. The Slovak Republic, UNCITRAL, PCA Case No. 2008-13 (korábban Eureko B.V. v. The Slovak Republic)

${ }^{21}$ Agreement on encouragement and reciprocal protection of investments between the Kingdom of the Netherlands and the Czech and Slovak Federal Republic (1991) - Hollandia-Szlovákia BIT (megszüntetve: 2021. 03. 31.)

22 Uo. 8. cikke. 
ban, így a választott bíróság megszorítóan és a BIT rendelkezéseinek megsértésére fókuszálva alkalmazhatja az uniós jogot. ${ }^{23}$

Miután a választott bíróság döntését meghozta, amelyben elmarasztalta az alperest, Szlovákiának a német jog mint alkalmazandó jog rendelkezései ${ }^{24}$ lehetőséget biztosítottak az ügy fellebbviteli fórum előtti megvitatására. Ekképpen végül a Német Szövetségi Legfelsőbb Bíróság, a Bundesgerichtshof kezdeményezett előzetes döntéshozatali eljárást az EUB előtt.

\subsection{Az EUB szerinti értelmezés}

Az előzetes döntéshozatali eljárás alapjául szolgáló kérdések az EUMSZ - mint uniós primer jogforrás - 267. és 344. cikkéhez, illetve 18. cikkéhez kapcsolódtak. Viszont az ügyben az EUMSZ 267. és (implicit módon) 344. cikkének, tehát az uniós jognak a BIT választottbírósági klauzulájával való összeegyeztethetősége vált központi kérdéssé.

Az EU jogrendje eredendően pluralista jellegének következtében az uniós jog értelmezése és alkalmazása addig nem összeegyezhetetlen az uniós joggal, amíg az EU képes fenntartani autonómiáját (Amariles et al., 2020:920). Az EUB, ahogy döntésében is rámutat, nem ismeri el „tagállami bíróságként” sem az ad hoc módon létrejött választottbírósági paneleket, sem a Washingtoni Konvenció ${ }^{25}$ égisze alatt létrejött ICSID nemzetközi beruházási választott bíróságot, ${ }^{26}$ ami azt eredményezi, hogy elözetes döntéshozatali eljárás keretében ezek a vitarendezési fórumok nem fordulhatnak az uniós bírói fórumhoz. Az EUB tehát az uniós jog alapvető tételeiből és az azokból levont következtetésekböl eljutott ahhoz a ponthoz, hogy a választottbírósági klauzula alkalmazása két tagállam között - ami az uniós jog lefedettsége alatt áll -, ezzel a joggal összeegyeztethetetlen. A jog strukturális oldaláról nézve kiemelt a fennálló társadalmi, jogi környezet teljes körủ védelmére irányuló törekvés. Az EU jogi természetéből eredendően helyezi védelmébe az uniós jogot. Az Achmea-ítélet viszont éppen e politikafilozófiai megfontolásai miatt kapta a legtöbb bírálatot. ${ }^{27}$ Sőt, egyes megközelítések szerint „autonómiavédő” kimenetelű verdikt-

${ }^{23}$ Achmea B.V. v. The Slovak Republic, UNCITRAL, PCA Case No. 2008-13 278-283. p.

${ }^{24}$ Zivilprozessordnung § 1059. (Aufhebungsantrag)

${ }^{25}$ Convention On The Settlement Of Investment Disputes Between States And Nationals Of Other States - 1987. évi 27. törvényerejü rendelet - az Államok és más államok természetes és jogi személyei közötti beruházási viták rendezéséről szóló, Washingtonban, 1965. március 18-án kelt Egyezmény kihirdetéséröl.

${ }^{26}$ The Slovak Republic kontra Achmea BV, EUB ítélet 43-44., 49. p.

27 Lásd Gáspár-Szilágyi, Sz. (2018). It Is not Just About Investor-State Arbitration: A Look at Case C-284/16, Achmea BV. European Papers, 3(1), 357-373; Hindelang, S. (2018). The Limited Immediate Effects of CJEU's Achmea Judgement. Verfassungsblog on Matters Constitutional, March 09. https:// verfassungsblog.de/the-limited-immediate-effects-of-cjeus-achmea-judgement/ 
A nemzetközi beruházási konfliktusok vitarendezésének sajátos útja...

ként értékelhető, ami a belső, tagállamok közötti beruházásvédelmi kérdések tisztázása helyett inkább a nemzetközi jog és uniós jog közötti reláció értelmezésére irányult (Mohay, 2019:54).

Az EUB döntésének végső következtetése az alábbi:

„,...) az EUMSZ 267. és 344. cikket úgy kell értelmezni, hogy azokkal ellentétes a tagállamok között létrejött nemzetközi megállapodásban szereplö olyan rendelkezés, amelynek értelmében e tagállamok egyikének beruházója a másik tagállamban létesitett beruházásokra vonatkozó vita esetén ezen utóbb tagállammal szemben választottbíróság elött indithat eljárást."

Ez az ítélet a hatékony bírósági felülvizsgálat sérelme miatt a szerződést kötő felek szabadságának gátját szabta. Sőt, a két tagállam közötti BIT-ről szóló ítélet de facto kiterjesztette hatályát az összes tagállami beruházási megállapodás ISDS kikötésére.

A döntésben viszont az EUB nem fejtette ki az EUMSZ 18. cikkével való összeegyeztethetőséget, és nem foglalkozott a BIT-ek tartalmával, azok hatályával sem. Sőt, az ítélet 57. pontja értelmében az EUB fenntartja annak eshetőségét, hogy egyes nemzetközi megállapodások rendelkezhetnek az értelmezésükre hivatott bíróság létrehozásáról, feltéve hogy nem jár az uniós jog sérelmével. Az Achmea-ítélet e sarkalatos pontjaival, vagy épp azok hiányával biztosítja az elegendő mozgásteret ahhoz, hogy az uniós jog és a nemzetközi jog közötti konfliktus feloldásához bizonyos fokú uniós megközelítéssel, de hozzájáruljon (Amariles et al., 2020:926). Nem mindegy tehát, hogy egységes vagy koherens jogrendkép mutatkozik-e a vizsgált uniós törekvések kapcsán. Ez mindig az EU aktuális realitásán alapul, azt vizsgálva, hogy a normatív képesség kielégítéséhez melyik alkalmasabb (Avbelj, 2006:391).

Az Achmea-ítélet elemzéséből úgy tủnik, hogy egy mérsékelt pluralista modell (Amariles et al., 2020:909) képét bontakoztatta ki az uniós jog és nemzetközi jog közötti diszharmóniában. Ennek következményeként a Bundesgerichtshof az EUB döntésében foglaltaknak eleget téve - tekintettel az uniós jog elsőbbségére - hatályon kívül helyezte a választott bíróság által hozott határozatot. ${ }^{28}$

\subsection{Az EUB-döntésre reflektáló nemzetközi jogi lépések}

Az ítélet újabb fejezetet nyitott az uniós beruházásvédelmi jog kialakítására tett törekvésekben, ami alapján kétségessé vált az EU tagállamai között hatályban lévő közel kétszáz beruházásvédelmi megállapodás választottbírósági eljárásra irányuló rendelkezése.

${ }^{28}$ German Federal Court of Justice, Decision, Case I ZB 2/15 (31 October 2018). 
A konfliktus pragmatikus feloldása helyett a döntés dichotómiája további jogi lépések megtételét irányozta elö. Az uniós jognak az EUB által helytelennek minősített értelmezése miatt a nemzetközi választott bíróságok, ad hoc választottbírósági panelek továbbra is fenntartották joghatóságukat. Az UP kontra Magyarország-ügyben hozott választottbírósági döntés ${ }^{29}$ elsősorban az ICSID létrejöttéről szóló nemzetközi egyezmény miatt vonatkoztatott el az Achmea-ítélettől. Szerinte a felek kifejezett akarata jelenik meg abban, hogy mindkét állam elfogadta a Washingtoni Konvenció által létrejött nemzetközi választott bíróság alkalmazását, így annak 54. cikke kötelezi az államokat az adott ügyben eljáró panel döntésének elismerésére és végrehajtására. Másrészt, ha Magyarország 2004. május 1-jei uniós csatlakozása implicit felülírja a BIT-ek hatályban maradását, akkor a kétoldalú megállapodás ún. sunset klauzulája biztosítja a szerződésből eredő jogok gyakorlását és kötelezettségek teljesítését még további - a felek akarata szerint meghatározottan akár - 20 évre.$^{30}$ Tehát az uniós jog általi értelmezés nem írhatja felül az egyes államok nemzetközi kötelezettségeit, így nem szolgálhat azok teljes és korlátlan értelmezéséül sem.

Következésképpen nemzetközi jogi környezetben e döntés által a BIT-ek nem szüntek meg, azok választottbírósági eljárásra irányuló rendelkezései hatályosak. Egy BIT, függetlenül attól, hogy az uniós jog kontextusában már tagállamok között áll fent, nemzetközi szerződés két állam között.

A rezsimek közötti konfliktus feloldásának elősegítéséhez és tisztázásához további jogi lépések szükségesek. Sőt, az Achmea-ítélet eredményeként nem csupán a tagállamok közötti BIT-ek rendszere vált kérdésessé, hanem az 1994-ben létrejött Energia Charta Egyezmény (Energy Charter Treaty - ECT) ISDS-kikötésének EU-n belüli alkalmazhatósága ${ }^{31}$ vagy éppen az EU Kanadával kötött szabadkereskedelmi megállapodásban létrehozott ICS (Investment Court System) rendszer is, amely egy beruházási vitákkal foglalkozó bírósági rendszert irányzott elő.

\section{Az Achmea-ügy hozadéka}

A Szlovák Köztársaság kontra Achmea-ügy döntése kizárólag az ISDS kikötésre összpontosított, amely kimondta a választott bíróságok, az eljáró ad hoc panelek

${ }^{29}$ UP (korábban Le Chèque Déjeuner) and C.D Holding Internationale v. Hungary, ICSID Case No. ARB/13/35.

${ }^{30}$ UP and C.D H Internationale v. Hungary, ICSID Case No. ARB/13/35, Award (9 October 2018) 252-265. p.

${ }^{31}$ Az Energia Charta Egyezményhez csatlakozott mind az EU, mind a tagállamok. 
alkalmazásának uniós joggal való összeegyeztethetetlenségét. Ezáltal az EU-ban lezajló reformok 2020 tavaszán valamennyi tagállam részvételével egy plurilaterális megállapodás megszületését eredményezte az intra-EU BIT-ek megszüntetéséről, ${ }^{32}$ ami már több BIT-nek is véget vetett. ${ }^{33}$

Másrészt az Achmea-ítélet 57. pontja is megerösítésre került. Az EUB 1/17 véleménye ${ }^{34}$ kifejezetten fenntartotta az egyrészről Kanada, másrészről az Európai Unió és tagállamai közötti átfogó gazdasági és kereskedelmi megállapodás (CETA) esetében azt a lehetőséget, hogy bizonyos feltételek mellett elfogadott más bíróság joghatósága, ha az nem tudja befolyásolni az uniós jogrend autonómiáját. Indokolása ebben az esetben az EUMSZ 344. cikkéből származtatott alapelvek megjelenésének hiányában rejlik. A CETA részletszabályai olyan biztosítékot teremtenek, amelyek védik az uniós jogrend autonómiáját. ${ }^{35}$

Viszont az EU és a tagállamok által aláírt Energia Charta Egyezmény és az abból eredö beruházási vitarendezés jelen helyzetét továbbra is jogbizonytalanság jellemzi. A kezdeti megalkuvásos értelmezést a nemzetközi jog oldaláról - amely szerint mind a BIT-ek rendszere, mind az uniós jog egymás mellett alkalmazható és alkalmazandó ${ }^{36}$ - felülírta ez a döntés. Ugyan az esetjogban a vitarendező arbitrázs elismerte, hogy az EUMSZ és az EUSZ is a nemzetközi szerződések részét képezik, így az ebből levezetett uniós jog elsőbbségi értelmezése elfogadott, azonban nem a bíróság hatáskörének kérdésében. ${ }^{37}$ Bár explicit módon az Achmea-ítélet nem utalt az ECT-ből eredő jogviták rendezésére, de lényegében, ha egy uniós tagállam beruházója egy másik tagállammal szemben indít választottbírósági eljárást az ECT

${ }^{32}$ Megállapodás az Európai Unió tagállamai közötti kétoldalú beruházási megállapodások megszűnéséről (HL 169/1. 2020. 05. 29.) - kihirdetve: 2020. évi LXI. törvény.

${ }^{33}$ Egy-egy BIT megszüntetéséhez mindkét tagállam ratifikációja - elfogadó vagy jóváhagyó nyilatkozata szükséges (kivételt képez annak ideiglenes alkalmazása).

${ }^{34}$ 1/17 vélemény (ECLI:EU:C:2019:72).

${ }^{35}$ Uo. 70-78. p.

${ }^{36}$ Pl. Eastern Sugar B.V. (Netherlands) v. The Czech Republic, SCC Case No. 088/2004. Partial Award March 272007 169. p.: a BIT és az Unióban meghatározott jogok és alapvető szabadságok nem ellentétesek és nem is konkurálnak, hanem kiegészítik egymást. Electrabel S.A. v. Republic of Hungary, ICSID Case No. ARB/07/19. Decision on Jurisdiction, Applicable Law and Liability November 30 2012 4.191. p.: választott bíróság előtt indítható eljárás Magyarország ellen, de uniós jogi kötelezettségek miatt tartalmilag korlátozható a beruházók védelme.

${ }^{37}$ Pl. Masdar Solar \& Wind Cooperatif U.A. v. Kingdom of Spain, ICSID Case No ARB/14/1, Award, 16 May 2018; Vattenfall AB and Others v. Federal Republic of Germany, ICSID Case No ARB/12/12, Decision on the Achmea issue, 31 August 2018; Foresight Luxembourg Solar 1 S.A.R.L. and Others v. Kingdom of Spain, SCC Arbitration V (2015/150), Final Award, 14 November 2018; Greentech Energy Systems A/S, NovEnergia II Energy \& Environment (SCA) SICAR, and NovEnergia II Italian Portfolio SA v. Italian Republic, SCC Arbitration V (2015/095), Final Award, 23 December 2018. 
hatálya alá tartozó kötelezettség megsértése kapcsán, akkor az analógia fennáll a megszüntetés alatt álló intra-EU BIT-ek rendszerével. Jogi aggálya azzal kapcsolatos, hogy ez már a jogi pluralista szemléletmód újabb dimenziója, hiszen az ECT egy olyan többoldalú megállapodás, amelynek mind az EU, mind a tagállamok tagjai. A szerződés egyetlen cikke sem rendelkezik az uniós reláció egyediségéről és egyetlen tagállam által tett nyilatkozatot sem hoztak azzal kapcsolatban, hogy az ECT 26. cikkének választottbírósági eljárásra és az alkalmazandó jogra vonatkozó rendelkezései az uniós joggal való összeegyeztethetetlenség miatt ne lennének irányadóak. Holott az ECT-hez történő csatlakozáskor felmerült egy elválasztó klauzula alkalmazásának gondolata, amely a tagállamok javára gondoskodott volna az uniós jog elsőbbségéről, mégsem foglalták bele az egyezménybe. ${ }^{38}$ Ezt megerősíti az ECT 46. cikke is, amely a megállapodáshoz füzhető fenntartások teljes körü kizárásáról rendelkezik. Kérdésként felvetődik, hogy nemzetközi jogi környezetben az uniós jog sajátos, elsőbbségi jellege mennyire képes érvényesülni.

Az ECT-tárgyalások az egyezmény modernizálásának tárgyában jelenleg is folynak, ám még inkább megnehezíti a helyzetet, hogy az EU által javasolt tervezet sem tartalmazza az ECT 26. cikkéhez fentebb említett kikötést. Belgium 2020 decemberében kérte az EUB véleményét annak megállapítására, hogy az ECT modernizációjára irányuló uniós törekvésben az ISDS-kikötés alkalmazása megfelel-e az Achmea-ítéletben foglaltaknak. Ennek elemzése alatt különösen hangsúlyos szerepbe kerülhet az ECT 16. cikkének értelmezése, miszerint az ECT két vagy több szerződő fele közötti korábbi vagy későbbi nemzetközi megállapodásban a vitarendezés tárgyára is vonatkozó részt nem szükséges vizsgálni, amennyiben az ECT-megállapodásban foglaltak kedvezőbb feltételeket biztosítanak a beruházók számára. A szerződés e cikke a lex specialis derogat legi generali elvet hivatott képviselni. A vitarendezés választott bíróságon keresztüli alkalmazása többletjogosultság a beruházókra nézve, így az ECT 16. cikke biztosítja a vitarendezésre vonatkozó 26. cikk érvényesülését is. Továbbá az egyezmény esetleges modifikációja is kérdéseket vethet el a BE 41. cikk 1. bekezdésének (b) pontja értelmében, hiszen a többoldalú szerződésben részes felek csak annyiban köthetnek a megállapodás megváltoztatásáról szóló megállapodást, amennyiben a kérdéses megváltoztatást a szerződés nem tiltja. Vagyis nem vonatkozhat olyan rendelkezésre, amelytől való eltérés összeegyeztethetetlen a szerződés céljának eredményes megvalósulásával. Ellenben az ECT 2. cikke kifejezi, hogy az egyezmény célja egy olyan jogi keret létesítése az energiaszektor-

${ }^{38}$ Communication from the Commission - The European Energy Charter: fresh impetus from the European Community, COM(93) 542 final of 4 November 1993, 6. p. 
A nemzetközi beruházási konfliktusok vitarendezésének sajátos útja...

ban folytatott hosszú távú együttmüködés előmozdításában, amely egymást kiegészítő és kölcsönös elönyökön nyugszik.

Ha az Achmea-ítélet hatására megtett jogalkotói lépésekből, az expanziós törekvésekből indulunk ki, az EU és a tagállamok számára akár az ECT felmondása is szóba kerülhet. ${ }^{39}$ Ennek bizonyosságára azonban várni kell az EUB-vélemény meghozataláig, vagy épp a folyamatban lévő előzetes döntéshozatali eljárások lezárultáig. ${ }^{40}$

\section{Záró gondolatok}

Az EUB az Achmea-ítélettel ugyan bővíthette az acquis communautaire körét, de a rá reflektáló jogi környezet eltérően vélekedett róla. A jogi pluralizmus létezése továbbra is tényként kezelendő, a jogrendek egyidejü interakciója képes lehet egyazon jogviszony szabályozására (Amariles et al., 2020:941). Látva az uniós jog és a nemzetközi jog közötti beruházásvédelmi jogi szabályozást, ebben az esetben hatványozottan igaz a kijelentés, hogy többdimenziós kérdéskört ölelt fel.

Az EU természetéből eredően helyezte védelmébe az uniós jogot, hiszen esetében a jog, a jogi szabályozás több mint pusztán politikai célkitüzések megvalósításának eszköze. Létének alapja és előfeltétele. Bár kívülről úgy tűnhet, hogy ez a jogpolitikai expanzió intézményi önérdeket takar, de az autonómia védelme több mint bírói uniós egoizmus: védi a jogállamiságon alapuló nemzetek feletti közösségi jogi érdekeket. Ebből a perspektívából kiindulva az EUB döntése megalapozott volt, azonban rövid terjedelme magában hordozta a konstruktív kétértelmüséget (Amariles et al., 2020:908), amelynek feloldására már nem maga az EUB képes, hanem a jogalkotással felruházott szerv, illetve a döntést követő jogalkotói mechanizmus.

Az Achmea-ítélet 57. pontjában fenntartotta annak eshetőségét, hogy egyes nemzetközi megállapodások rendelkezhetnek az értelmezésükre hivatott bíróság létrehozásáról, aminek eredményeképpen kiértékelhette az ICS-mechanizmust, viszont nem válaszolta meg az előzetes döntéshozatali kérelemben feltett összes kérdést, különös tekintettel az EUMSZ 18. cikkére, amely a megkülönböztetés tilalmáról rendelkezik. Az Achmea-döntés kapcsán ezzel a cikkel a belső piac versenyfeltételeinek torzító hatása vizsgálható lett volna, és az intra-EU BIT-rendszer megszüntetésének

${ }^{39}$ EB 2020. december 2-án tett nyilatkozata: „,i]f core EU objectives ... are not attained within a reasonable timeframe, the Commission may consider proposing other options, including the withdrawal from the ECT".

${ }^{40}$ L. C-742/19. sz. ügy The Republic of Moldova kontra Komstroy (Energoalians) ügy; C-155/21. sz. ügy The Republic of Italy kontra Athena Investments and Others. 
kiemelt érve lehetett volna. Ám az is valószínüsíthető lett volna, hogy ha az EUMSZ 18. cikke e döntés indokolásának részét képezte volna, akkor annak hatályát, ahogy értelmezésének mozgásterét is szúkítette volna. Az ítélet e sarkalatos pontjaival vagy épp azok hiányával biztosította az elegendő mozgásteret ahhoz, hogy az uniós jog és a nemzetközi jog közötti jogi pluralista nézetet, az érdekeket mérsékelt mederbe terelje, hogy majd a jogalkotás feloldja a rezsimek konfliktusát.

Bár az intra-EU BIT-rendszer megszüntetésére irányuló törekvések végül révbe érnek, az alkalmazandó jog bizonytalanságának korát zárva azonban további kételyek maradnak fent. Látva a joggyakorlatot, addig biztosan, amíg az adott tagállam befektetője a fogadó tagállammal szemben nemzetközi beruházási választott bíróság, ad hoc panel elött indít eljárást.

A tagállamok ugyan megszüntethetik szerződéseiket, azonban az EB által is erőteljesen támogatott ex tunc hatály alkalmazása aláássa e tagállamok nemzetközi kötelezettségeit, sőt az exporttámogató államok beruházóinak védelmét is. A 2020. évi megállapodás a tagállamok közötti beruházási szerződések megszűnéséről következetes lépés volt. Annak azon cikkei azonban, amelyek e szerződések rendelkezéseit visszaható hatállyal igyekeznek bojkottálni az Achmea-döntés óta született ügyek nemzetközi választott bíróságok vitarendezési paneljei előtt, a következetes jogalkalmazás és jogbiztonság szem előtt tartásával valószínűleg túlnőnek az uniós jogrenden. Hiszen hiába az uniós jogrend szupremáciájának és autonómiájának hirdetése, ha a tagállamok nemzetközi jogi kötelezettségvállalásai fennállnak. Mindezt olyan alapelvek létéből származtatva, amelyek a nemzetközi szokásjog alapját alkotják. A választott bíróságok értelmezésében a $\mathrm{BE}$ erre vonatkozó cikkeinek alapulvételével erős kritikák érik: túlzottan beavatkozott a tagállamok szuverenitásába, elötérbe helyezve az uniós jogot és tagadva a nemzetközi jog relevanciáját.

A nemzetközi jog és az uniós jog közötti kapcsolat összetett. A jog világában e két ág közötti reláció mindig is speciális téma volt, amit tovább fokoz a választottbírósági eljárások növekvő száma, az új beruházási vitarendezési mechanizmusok kidolgozása (Stoppioni, 2020:37). Különlegessége az EU pluralista jellegéből eredeztethető. Az uniós jogrend a nemzeti és nemzetközi jog találkozásának helye, amely végső soron feltételezi, sőt elismeri a nemzetközi jog létét, de fennhatóságát egyre inkább ki akarja terjeszteni. Esetkörében külső és belső pluralizmus egyaránt fennáll, hiszen az EU fokozott kommunikációja és integrációja a nemzetközi jogrendek felé nyitott, amit jelen témához kapcsolódóan mi sem bizonyít jobban, mint az ECT-hez történő csatlakozás. Ezáltal azonban felelőssége is fokozódik. Hogyan 
képes befogadni a pluralizmus mindkét típusát, miközben az uniós jog hatékonyságát is biztosítani szeretné (Amariles et al., 2020:932)?

El kell ismerni, hogy a tagállamok között köttetett beruházásvédelmi szerződések is olyan jogi konstrukciók, amelyek a nemzetközi jogban teljesednek ki (Wychera \& Mimnagh, 2019:408). A különféle jogi rezsimek jogviszonyokra történő egyidejü ráhatása valójában a jogbiztonság és jogfolytonosság szabotázsaként értékelhető.

Viszont nem szabad elfelednünk, hogy jelen állapot csupán egy átmenet, és az uniós törekvések helyes irányban tartásának megerősítésére a mércét továbbra is az objektív jogi alapok nyújtják, amelyek már túlnőnek az EUB jogalkalmazási és jogértelmezési hatáskörén. Az Achmea-ítélet előszele volt az uniós jog expanziós viharának, amelynek a jogalkotói mechanizmusok vethetnek majd véget, de a kérdés - amelyre választ a jövőben kaphatunk csak - fennmarad, hogy mégis milyen végkifejlettel.

\section{Hivatkozások}

Amariles, R. D., Farhadi A. A. \& van Waeyenberge, A. (2020). Reconciling International Investment Law and European Union Law in the Wake of Achmea. International and Comparative Law Quarterly, 69(4), 907-943. Doi:10.1017/S0020589320000299

Avbelj, M. (2006). The EU and the Many Faces of Legal Pluralism Toward a Coherent or Uniform EU Legal Order? Croatian Yearbook of European Law and Policy, 2, 377-391.

Bartha, I. (2015). Nemzetközi szerződések mozgásban. Budapest, Pécs: Dialóg Campus Kiadó

Griffiths, J. (1986). What Is Legal Pluralism? Journal of Legal Pluralism, 18(24), 1-55.

Mohay, Á. (2019). Külső fórumok és az uniós jog autonómiája. In Kis, K. B., Mohay, Á \& Pánovics, A. (szerk.), Ünnepi tanulmánykötet Bruhács János 80. születésnapja tiszteletére, PTE-ÁJK.

Nagy, Cs. I. (2018). Intra-EU Bilateral Investment Treaties and EU Law After Achmea: "Know Well What Leads You Forward and What Holds You Back". German Law Journal, 19(1), 981-1016.

Prieto-Rios, E. (2015). Neoliberal Market Rationality: The Driver of International Investment Law. Birkbeck Law Review, 3(1), 55-76.

Somssich, R. (2019). Az Európai Bíróság. In Arató, K. \& Koller, B. (szerk.), Az Európai Unió politikai rendszere. Budapest, Pécs: Dialóg Campus Kiadó.

Stoppioni, E. (2020). The Interactions between EU Law and International Investment Law: The Five Acts of a Kabuki Play. Hitotsubashi Journal of Law and Politics, 1(48), 37-52.

Subedi, P. Surya (2016). International Investment Law: Reconciling Policy and Principle. Hart Publishing, Third Edition.

Szabados, T. (2017). A tagállamok közötti beruházásvédelmi egyezmények az uniós jogban. Állam- és Jogtudomány. 8(3), 17-44.

Wychera, B. \& Mimnagh, W. (2019) The Nature of State Consent Expressed in BITs. In: Klausegger, C., Klein, P., Kremslehner, F., Petsche, A., Pitkowitz, N, Welser I. \& Zeiler. G. (Eds.): Austrian Yearbook on International Arbitration 2019. Wien: MANZ Verlag. 